oil, cetane, and standard mixture (a mixture of $37.5 \%$ isooctane, $37.5 \%$ cetane, and $25 \%$ benzene) used as standard materials for the determination of the oil by infrared absorption method showed fairly different data when measured with both NDIR and IRSP (Table 1). It must be noticed that the oil content in waste water are different according to the choice of the standard materials.

(Received Apr. 13, 1979)

\section{Keywords}

Infrared analysis

Infrared spectrophotometer

Nondispersive infrared analyzer

Oil

Standard material

Waste water

\title{
アクリル緎維のけい光 $\mathbf{X}$ 線分析のための試料成形法
}

\author{
伊藤 元, 寒竹 嘉彦®, 川村 富彦, 吉田 政雄* \\ (1979 年. 6 月 9 日受理)
}

\begin{abstract}
けい光X線分析のためにアクリル織維を粉末化する方法について研究した．ここで開発した方法は, 䋐維を石英片とともに振り混ぜて切断粉末化するものである。この方法をアクリル䋐維中に含をれる $(0.1 \sim 0.5)$ 重量\%の範囲のスズの定量に用いた. 粉末化の可能性と測定 $\mathrm{X}$ 線強度は，緘維と石英の比 と混合時間に依存していた。 $2.00 \mathrm{~g}$ の紻維と $4.50 \mathrm{~g}$ の石英を 60 分間混合した場合に最良の結果が得 られた．この粉末を $10 \mathrm{ton} / \mathrm{cm}^{2}$ の荷重で加圧成型した。 スズは同時に溶液法によっても定量し，二つ の定量值の偏差は $(0.01 \sim 0.06) \%$ であった．この方法は繊維中の他元素の分析にも応用可能である.
\end{abstract}

\section{1 緒 言}

けい光X線分析法によるポリマー中の元素の定量分析 は従来から数多くの報告があり, そのための試料調製法 も目的元素の種類, ポリマーの種類により多岐にわたっ ている.

例えば，熱可塑性ポリマーの場合には加熱溶融するこ とにより平滑な平面を得ることができる.しかし，不溶 融あるいは加熱時に熱分解が先行する, ポリアクリロニ トリル, ビスコースレーヨン，ポリ塩化ビニルには適用 できない。

他に溶液法, 織維を巻き付ける方法, マイラーフィル ムにはさむ方法, 樹脂でかためる方法2), 繊維を凍結粉 砕する方法があるが，しかし，これらの方法は定量性， 操作性などの点でいずれも十分とはいえない.

そこで著者らは, 石英を粉砕助戍として瀻維を粉砝す ることにより，一度に多量の試料を調製することができ たので報告する.

* 三菱レイヨン(株)研究所: 広島県大竹市御幸町 20-1

\section{2 装置及び試薬}

\section{1 装}

けい光 $\mathrm{X}$ 線分析装置: 理学電機社製，ガイガーフレッ クス $\mathrm{S}$ 型けい光 $\mathrm{X}$ 線分析装置にフィリップス社製管球 （タングステン対陰極及びクロム対陰極： $2.7 \mathrm{~kW}$ ) を装 着して使用した。

ミキサーミル：スペックス社製ミキサーミルを使用し た.

\section{2 試 薬}

ボリアクリロニトリル䋐維: アクリロニトリルと塩化 ビニリデン $(4: 1)$ の共重合体から成る瀻維で, 瀻度は 5 デニールである， 又，安定棛としてスズ化合物を合む.

ポリアクリロニトリル粉末：アクリロニトリルと塩化 ビニリデン $(4: 1)$ の共重合体の粉末で，200メッシュ 通過部分を用いた。これは安定郕を含まない。

ホウ酸, 塩化スズ(II)：石津製薬製特級試薬を使用し た.

石英：石英管（直径 $10 \mathrm{~mm}$ ）を所定量切断して使用 した.

$N, N$-ジメチルホルムアミド (DMF) : 和光純薬製特 級試薬を使用した。 
又，スズの定量のための標準試料はポリアクリロニト リル粉末 $5 \mathrm{~g}$ に塩化スズ(II) $3 \%$ 水溶液を既知量加え, ロータリーエバボレーター内でかくはん，乾燥して調製

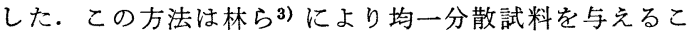
とが報告されているが，確認のためこうして得た粉末を そのまま加圧成形し，スズの $\mathrm{K}_{\alpha}$ 線強度を測定し，スズ 添加量に対してプロットした結果良好な直線関係を得た ので, 添加したスズは均一に分散していると判断した.

\section{3 結果と考察}

本法は粉砕助剤により繊維を粉砕するものである。そ こで粉砕助剤の選択, 粉砕時間, 混合比について検討し た. 以下の検討にはポリアクリロニトリル繊維を供し た.

\section{1 粉碎助冎潠択及び混合比率}

粉砕助剂としては，ホウ酸を溶融し冷却後塊状にした 溶融物, 石英について検討した.

試料と粉砕助剤の比率を $0.2 \mathrm{~g} / 4.5 \mathrm{~g}$ とすると, 加圧 成形性が悪いかもしくは成形不可能であった。しかし， $2.0 \mathrm{~g} / 4.5 \mathrm{~g}$ で混合すると成形可能となった.

次に，ホウ酸又は石英を粉砕助剤としたときの分散の 均一性について検討した，共重合成分に基づく塩素 $\mathrm{K}_{\boldsymbol{\alpha}}$ 線強度の試料間の再現性が高いほうが，均一であると考 えられる. そこで， ホウ酸溶融物又は石英 $4.5 \mathrm{~g}$ と試料 $2.0 \mathrm{~g}$ を 45 分間混合して成形した後, 塩素 $\mathrm{K}_{\alpha}$ 線の強 度を測定した.このときの測定条件と結果を Table 1, 2 に示す.

Table 1 Conditions of X-ray spectrometer for the measurement of chlorine $\mathrm{K}_{\alpha}$

\begin{tabular}{ll}
\hline Target & Cr $(25 \mathrm{kV}, 40 \mathrm{~mA})$ \\
Crystal & EDDT \\
Detector & PC \\
Analytical line & Cl K $\mathrm{K}_{\alpha} 1.2$ (1st) \\
Path & Vac. \\
\hline
\end{tabular}

Table 2 Measurement of chlorine $\mathrm{K}_{\alpha}$ influence of milling agent

\begin{tabular}{lcc}
\hline \multicolumn{1}{c}{ Milling agent } & Boric acid & Quartz \\
\hline Mean of intensity of chlorine $\mathrm{K} \alpha(n=4)$ & 28100 & 10520 \\
Standard deviation & 550 & 120 \\
Coefficient of variance & $1.9 \%$ & $1.1 \%$ \\
\hline
\end{tabular}

\section{2 混合時間}

粉砕助剂との混合時間についても，3.1 と同様にして 分散の均一性をもって判断した。

30 分間混合した場合には，繊維が十分に切断されて
いないことが肉眼で観察された．そこで，混合時間 45 分間及び 60 分間の試料を各々 3 点ずつ試料を成形して, 試料間の特性 $\mathbf{X}$ 線強度の再現性を比較した。ここでは後 に述べるように，溶液法との比較により本法の妥当性を 判断することを意図しスズの定量性について検討した. そこで，スズの $\mathrm{K}_{\alpha}$ 線強度についても同様に測定した。 その測定結果を Table 3，5 に示す.

Table 3 Influence of milling time on the intensity of chlorine $\mathrm{K}_{\alpha}$

\begin{tabular}{lcc}
\hline \multicolumn{1}{c}{ Milling time } & $45 \mathrm{~min}$ & $60 \mathrm{~min}$ \\
\hline Mean of intensity of chlorine $\mathrm{K} \alpha \quad(n=3)$ & 10520 & 9970 \\
Standard deviation & 100 & 50 \\
Coefficient of variance & $0.9 \%$ & $0.5 \%$ \\
\hline
\end{tabular}

Table 4 Conditions of X-ray spectrometer for the measurements of tin $\mathrm{K}_{\boldsymbol{\alpha}}$

\begin{tabular}{ll}
\hline Target & W $(45 \mathrm{kV}, 25 \mathrm{~mA})$ \\
Crystal & $\mathrm{LiF}$ \\
Detector & $\mathrm{Sc}$ \\
Analytical line & Tin K $\alpha 1.2$ (1st) \\
\hline
\end{tabular}

Table 5 Influence of milling time on the intensity of tin $\mathrm{K}_{\alpha}$

\begin{tabular}{lcc}
\hline \multicolumn{1}{c}{ Milling time } & $45 \mathrm{~min}$ & $60 \mathrm{~min}$ \\
\hline Mean of intensity of tin $\mathrm{K}_{\alpha}(n=3)$ & $4890 \mathrm{cps}$ & $5480 \mathrm{cps}$ \\
Standard deviation & 90 & 50 \\
Coefficient of variance & $1.8 \%$ & $0.9 \%$ \\
\hline
\end{tabular}

この結果から， 60 分間混合することにより試料調製 は十分に再現されることが明らかである。

$3 \cdot 1,3.2$ の検討の結果に従って以後は次のような試 料調製を行った.つまり, 試料 $(2.000 \pm 0.001) \mathrm{g}$ と石 英 $(4.500 \pm 0.001) \mathrm{g}$ を正確にひょう量し，ミキサーミ ルで60 分間混合して 10 ton $/ \mathrm{cm}^{2}$ で加圧成形する.

\section{3 検吾線の作成}

実験の項で述べた標準試料粉末を 3.2 の方法で成形し た. このときのスズの添加量，スズ $\mathrm{K}_{\alpha}$ 線強度の測定結 果を Fig. 1 亿示す. X 線強度の測定結果は不感時間の 補正を施した。このときの検量線推定誤差は $0.018 \%$ であった。

\section{4 溶液法との比較}

3.3 で検討したスズの定量については，溶液法のほう が精度及び正確さともに高いと考えられるので，本法で 


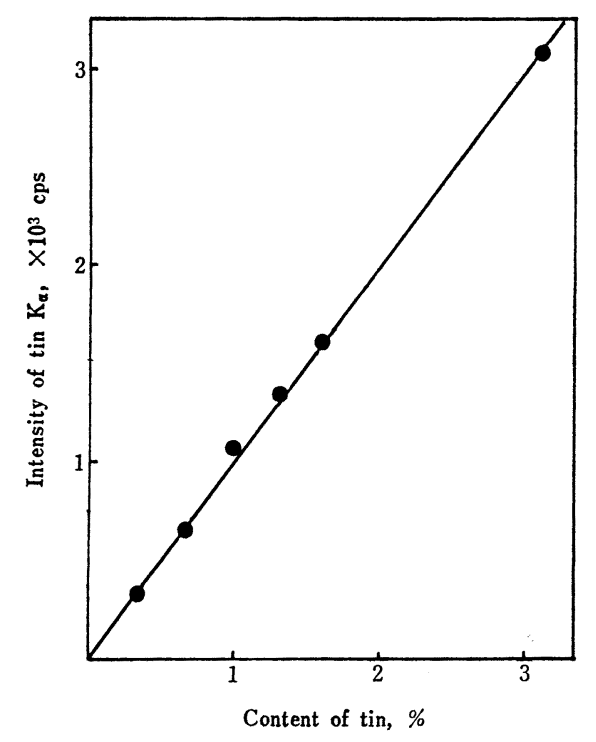

Fig. 1 Relationship between tin content and the intensity of tin $\mathrm{K}_{\boldsymbol{\alpha}}$ for polymer powdered with quartz

の定量值を溶液法と対比した. 溶液法はポリマー繊維又 は粉末を $5 \%$ DMF 溶液として測定した. その結果を Table 6 に示す. このときの検量線推定誤差は $0.023 \%$ であった.

Table 6 から明らかなように, 溶液法との相対偏差は 土10 以下である. しかし, 偏差が正負のいずれかに偏 っているものではないので, 分散性に若千問題を残して いるが，ほぼ満足すべき結果を得た。

Table 6 Comparison of sample preparation techniques of tin

\begin{tabular}{clcr}
\hline $\begin{array}{c}\text { Sample } \\
\text { No. }\end{array}$ & $\begin{array}{c}\text { Determination of tin in acrylic fiber } \\
\begin{array}{c}\text { Dissolving } \\
\text { technique } \\
\text { (A) }\end{array}\end{array}$ & $\begin{array}{c}\text { Milling } \\
\text { technique } \\
\text { (B) }\end{array}$ & (A)-(B) \\
\hline 1 & $0.30_{8} \%$ & $0.29_{7} \%$ & $0.01_{1} \%$ \\
2 & $0.54_{4}$ & $0.59_{8}$ & $-0.05_{4}$ \\
3 & $0.16_{8}$ & $0.14_{9}$ & $0.01_{9}$ \\
4 & $0.58_{0}$ & $0.51_{4}$ & $0.06_{6}$ \\
5 & $0.52_{7}$ & $0.48_{1}$ & $0.04_{6}$ \\
6 & $0.33_{5}$ & $0.30_{9}$ & $0.02_{6}$ \\
7 & $0.48_{5}$ & $0.51_{6}$ & $-0.03_{1}$ \\
\hline
\end{tabular}

$$
4 \text { 結言 }
$$

石英とともに混合して繊維状試料を粉砕し, けい光 $\mathbf{X}$ 線試料を調製することができた。

溶液法との相対偏差は約 $10 \%$ であった. この方法 は，ポリアクリロニトリル繊維に限らず他の繊維状物の 成形にも適用可能であると考えられる.

終わりに，この研究を進めるに当たり多大な援助と本 誌への投稿に賛同いただいた三菱レイヨン(株)研究所所 長山田信夫氏に謝意を表する. 又，援助，協力をいただ いた同研究所杉山道康氏に謝意を表する.

\section{交献}

1) W. S. Cook, G. O. Jones, A. G. Altenau : Can Spectroscopy, 1968, 64.

2) R. Jenkins, J. L. de Vries : "Practical X-Ray Spectrometry", 2nd Ed., p. 150 (1970) (Philips).

3) 林 正寿, 菅原浩二, 下條雅之：分化, 18, 862 (1969).

$$
\stackrel{s}{3}
$$

A sample preparation technique of acrylic fiber for X-ray spectrometry. Hajime ITo, Yoshihiko Kanchiku, Tomihiko Kawamura and Masao Yoshida (Central Research Laboratory, Mitsubishi Rayon Co., Ltd., 20-1, Miyuki-cho, Ohtake-shi, Hiroshima)

A new technique of powdering acrylic fiber was studied for X-ray spectrometry. In the technique developed here, fiber was cut and milled by shaking with quartz fragments. It was applied to the determination of tin in acrylic fiber in the range of $(0.1 \sim 0.5)$ weight percent. The ability of powdering and reproducibility of the measured $\mathrm{X}$-ray intensity depended on the weight ratio of fiber to quartz and mixing time. The best results were obtained when mixing $2.00 \mathrm{~g}$ of fiber with $4.50 \mathrm{~g}$ of quartz for $60 \mathrm{~min}$. The powder was pressed under the load of 10 ton/ $\mathrm{cm}^{2}$. Tin was determined by the dissolution technique at the same time and the deviation of the two different determinations was $(0.01 \sim 0.06) \%$. This technique is applicable to analyze the other elements in fibers by X-ray spectrometry.

(Received June 9, 1979)

\section{Keywords}

Fiber

Polyacrylonitrile

Sample preparation

Tin

$\mathrm{X}$-Ray fluorescence spectrometry 